\title{
Relationship Between Rhapidosome and Pyocin in Pseudomonas fluorescens
}

\author{
By K. AMAKO, K. YASUNAKA AND K. TAKEYA \\ Department of Bacteriology, School of Medicine, \\ Kyushu University, Fukuoka, Japan
}

(Accepted for publication 6 April 1970)

SUMMARY

Rhapidosomal rods released from strain 3R of Pseudomonas fluorescens appear to be polymerized sheaths of pyocin which had a structure like that of T-even phage tails. This conclusion was based on the following observations: (I) Morphologically the rods have the same structure and diameter as the contracted sheath of R-type pyocin. (2) They resemble the polysheath of T-even phages. (3) Antigenically they are similar to R-type pyocin. (4) They are usually induced together with R-type pyocin but not with 28-type pyocin.

\section{INTRODUCTION}

Since the discovery of rod-shaped particles in Saprospira (Lewin, I963), this kind of structure has been reported in several species of bacteria (Bradley, I967; Yamamoto, 1967; Reichenbach, I967; Ueda \& Takagi, I968; Clark-Walker, I969). Such rods found within or liberated from bacterial cells have been given the name 'rhapidosomes' (Lewin, 1963). Pate, Johnson \& Ordal (1967) suggested that they were degenerate forms of the membranous structure of host cells. Ueda \& Takagi (I968) explained rods in Clostridia in the same way. Recently many such structures have been reported in mitomycin-induced lysates of several species of bacteria (Bradley, 1967: Iida \& Inoue, I968; Clark-Walker, 1969); these rhapidosomes often appeared together with bacteriocins which had the structure of phage tails, and their origin might be different from that of the first type (Reichenbach, 1967; Clark-Walker, I969). Many members of the Pseudomonas group of bacteria are known to be pyocinogenic (Hamon, 1956). During the course of experiments on pyocin we discovered that some of them also produced the second type of rhapidosome. The relation between pyocin and rhapidosome was investigated and is reported in this paper.

\section{METHODS}

Bacteria. Strain 3R of Pseudomonas fluorescens isolated in our laboratory was used as the rhapidosome-producing organism. Activity of the released pyocin was titrated on the CI4 strain of $P$. aeruginosa (from Dr Homma of Tokyo University, Institute of Medical Science), who also provided strains P28, C I 8 and $\mathrm{K}$. The $\mathrm{FP}^{+}$strain was obtained from Dr T. Watanabe of Keio University, and other strains used in these experiments were isolated from patients at Kyushu University Hospital. All the strains were tested for the production of pyocin, rhapidosomes and phages. 
Media and cultivation of bacteria. Bacteria were grown in peptone broth or heart infusion broth (Difco) with aeration. GS medium, a synthetic medium, contained (g./l.): $\left(\mathrm{NH}_{4}\right)_{2} \mathrm{HPO}_{4}, 2 \cdot 5 \mathrm{~g} ; \mathrm{KH}_{2} \mathrm{PO}_{4}, \mathrm{I} \cdot 5 ; \mathrm{NaCl}, 5 \cdot 0$; sodium glutamate, $3 \cdot 0$; glucose, $3 \cdot 0 ; \mathrm{MgSO}_{4} \cdot 7 \mathrm{H}_{2} \mathrm{O}, 0 \cdot \mathrm{I} ; \mathrm{CaCl}_{2}, 0.05 ;$ yeast extract, $\mathrm{I} \cdot 0 ; \mathrm{pH} 7 \cdot 2$.

For induction, mitomycin $\mathrm{C}$ (Kyowa Hakko Kogyo Co. Ltd, Tokyo, Japan) was added to the culture in logarithmic phase at a final concentration of $3 \mu \mathrm{g}$. $/ \mathrm{ml}$. In experiments at temperatures other than $37^{\circ}$, cells growing logarithmically at $37^{\circ}$ were held at the designated temperature for $\mathrm{I} h$. and then induced by mitomycin.

Antisera and micro-agglutination technique. Antisera against pyocin were prepared as follows: Pyocin induced from strain $3 \mathrm{R}$ at $25^{\circ}$ was partially purified by differential centrifugation, then, mixed with Freund's adjuvant, it was injected intradermally into rabbits. Two weeks later a second injection was given without adjuvant, and ro days later blood was collected by heart puncture and serum was prepared. Antibodies against the components of the host cell were adsorbed with large amounts of host cells prior to use. The micro-agglutination technique of Hummeler, Anderson \& Brown, (I962) was used: serum was diluted ten times with phosphate-buffered saline $(\mathrm{pH} 7 \cdot 0)$ and mixed with an equal volume of concentrated pyocin prepared by concentrating the crude lysate of strain $3 \mathrm{R}$ by ultracentrifuging at $30,000 \mathrm{rev}$. $/ \mathrm{min}$. for $\mathrm{I} \mathrm{h}$.; it contained R-type and 28-type pyocins and rhapidosomes. After standing at room temperature for $30 \mathrm{~min}$., the mixture was centrifuged at $10,000 \mathrm{rev}$. $/ \mathrm{min}$. for $30 \mathrm{~min}$. The resulting pellets were resuspended in a small volume of $2 \%$ ammonium acetate solution and examined under the electron microscope.

Electron microscopy. Mitomycin-induced lysate was treated with desoxyribonuclease to reduce the viscosity due to host cell DNA, then after low-speed centrifugation to remove cell debris, pyocin and rhapidosomes were centrifuged down at 30,000 rev./ min. for $\mathrm{I} h$. Pellets were resuspended in $2 \%$ ammonium acetate solution and the suspension was negatively stained with neutral potassium phosphotungstate.

\section{RESULTS}

Effects of mitomycin $C$ on the growth of strain $3 R$. To logarithmically growing cells at $37^{\circ} 3 \mu \mathrm{g}$. of mitomycin $\mathrm{C} / \mathrm{ml}$. were added and cell growth was followed in terms of optical density at $660 \mathrm{~nm}$. For I h. after induction density of the culture increased parallel to that of the control, and then decreased rapidly (Fig. I).

Morphology of pyocin and rhapidosomes. Strain 3R produced two types of pyocin (Pl. I, fig. I). One, pyocin 28, had a structure similar to that of $\lambda$ phage tails (Takeya, Minamishima, Amako \& Ohnishi, 1967) and the other, pyocin R, resembled T-even phage tails (Ishii, Nishi \& Egami, I965). R-type pyocin had a contractile sheath with a diameter of $\mathrm{I} 50 \AA$ in the extended, and $\mathrm{I} 80 \AA$ in the contracted, state. Rhapidosomes were long rods $180 \AA$ in diameter (P1. I, fig. 2, 3). Since phosphotungstate penetrated into the rhapidosomes they are thought to be hollow, of internal diameter about $80 \AA$. Their granular appearance suggests that they are constructed of small irregularly arranged subunits (Pl. I, fig. 3).

Morphologically they resemble the polysheath of a T-even phage and might be polymerized sheath proteins of R-type pyocin.

Antigenic similarity of $R$-type pyocin and rhapidosomes. The suggestion of the last paragraph was investigated by specific micro-agglutination, as revealed by the electron 
microscope (Hummeler et al. 1962). It was found that R-type and 28-type pyocin formed specific agglutinates, and that rhapidosomes agglutinated with R-type, but not with 28-type pyocins (Pl. 2, fig. 4, 5; Pl. 3, fig. 6). Antibody bridges were clearly seen between rhapidosome and R-type pyocin (Pl. 2, fig. 5 arrow) indicating antigenic similarity of the two.

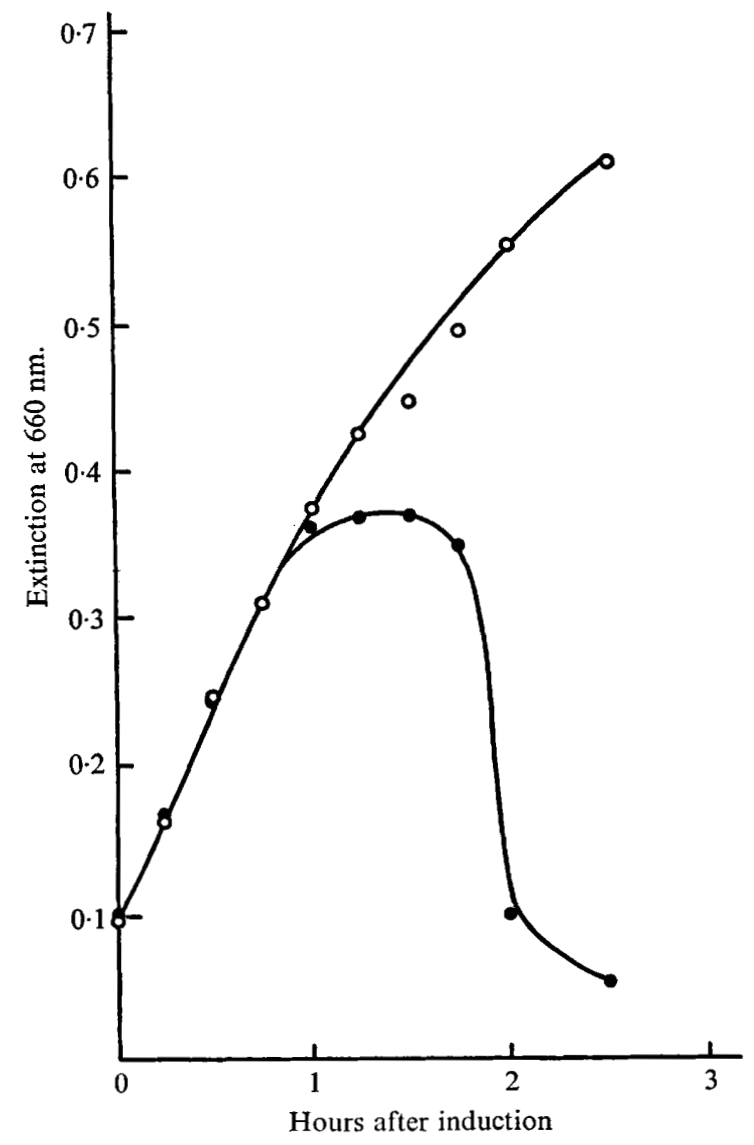

Fig. 1. Effect of mitomycin C on the growth of Pseudomonas fuorescens strain $3 \mathrm{R}$ at $37^{\circ}$. Mitomycin $\mathrm{C}$ was added to the logarithmic phase of the culture at a final concentration of $3 \mu \mathrm{g} . / \mathrm{ml}$. Growth was followed by observing changes in extinction $(E)$ at $660 \mathrm{~nm}$. Control, $\mathrm{O}-\mathrm{O}$; mitomycin-treated,

Conditions for rhapidosome production. The $3 \mathrm{R}$ strain was able to grow even in synthetic medium and to be lysed by mitomycin. Rhapidosome and pyocin production under various conditions is summarized in Table $\mathrm{I}$. When induction took place at low temperature $\left(25^{\circ}\right), 5 \mathrm{~h}$. or more were required for complete cell lysis (Fig. 2) and no rhapidosomes were produced.

The lysate obtained at $40^{\circ}$ contained small ring structures about ${ }_{\mathrm{I}} 20 \AA$ in diameter (PI. 3, fig. 7) as well as short rods which might be polymerized forms of these rings.

Production of rhapidosomes in several strains of the Pseudomonas group. Data obtained so far suggest that the rhapidosome released from strain $3 \mathrm{R}$ is a polymerized 
sheath protein of R-type pyocin. Accordingly, the relationship of rhapidosome and R-type pyocin production was investigated in several strains of the Pseudomonas group. Sixteen strains were induced with mitomycin $\mathrm{C}$, the lysates were negatively stained, examined under the electron microscope, and the presence or absence of R-type and 28-type pyocin, rhapidosomes and phages was recorded.

Table I. Production of rhapidosomes and pyocin by mitomycin induction from Pseudomonas fluorescens strain $3 R$ under various conditions

$\begin{array}{lcccc}\text { Medium } & \text { Temperature } & \begin{array}{c}\text { Cell } \\ \text { growth }\end{array} & \begin{array}{c}\text { Pyocin } \\ \text { production }\end{array} & \begin{array}{c}\text { Rhapidosome } \\ \text { production }\end{array} \\ \text { Heart infusion broth } & 40^{\circ} & + & + & + \\ & 37^{\circ} & ++ & ++ & ++ \\ \text { Peptone broth } & 28^{\circ} & ++ & ++ & ++ \\ \text { Synthetic medium } & 25^{\circ} & + & ++ & - \\ \text { (CS) } & 37^{\circ} & ++ & ++ & + \\ & 37^{\circ} & + & ++ & +\end{array}$

Table 2. Production of pyocin and rhapidosomes from several strains of the Pseudomonas group

$\begin{array}{lcccc}\text { Strain } & \begin{array}{c}\text { 28-Type } \\ \text { pyocin }\end{array} & \begin{array}{c}\text { R-type } \\ \text { pyocin }\end{array} & \text { Rhapidosome } & \text { Phage* } \\ \text { FP }^{+} & + & + & + & - \\ \text {3R } & + & + & + & - \\ \text { K } & + & + & + & - \\ \text { II } & + & + & + & + \\ \text { A 31 } & + & + & + & - \\ \text { 37 } & + & + & + & - \\ \text { 67 } & + & + & + & + \\ \text { B I0 } & + & + & + & - \\ \text { A 22 } & + & + & - & - \\ \text { 22 } & - & + & + & - \\ \text { B 62 } & - & + & - & - \\ \text { C 18 } & + & - & - & - \\ \text { P 28 } & + & - & - & - \\ \text { A 30 } & + & - & - & + \\ \text { B 46 } & + & - & - & + \\ \text { C 14 } & + & - & - & - \\ \text { B 52 } & - & - & - & -\end{array}$

* All phages induced from these strains are of $\lambda$ phage type.

As shown in Table 2 rhapidosomes were produced concomitantly with R-type pyocin but not with 28-type pyocin. Only in two strains (A 22, B 62) which formed R-type pyocin could no rhapidosomes be seen, but as they were often scanty it is possible that they were missed. Phages induced in these strains all had the structure of $\lambda$ phage.

\section{DISCUSSION}

It was concluded from these experiments that the rhapidosome induced from Pseudomonas is polymerized sheath protein of R-type pyocin. Morphologically it has the structure of the contractile sheath of the pyocin and it also resembles the polysheath which appeared in the lysate of a conditionally lethal mutant of T-even 
phage (Epstein et al. 1963). Rhapidosomes always have the same diameter as the contracted, not extended, sheath. The polysheath of the $\mathrm{T}_{4}$ mutant is the polymerized sheath protein of the phage tail and also has the structure of the contracted sheath (Kellenberger \& Boy de la Tour, 1964). Our micro-agglutination experiments showed that the rhapidosome and R-type pyocin have the same antigenicity, which supports the idea that the rhapidosome is made from the same protein as the sheath of R-type pyocin.

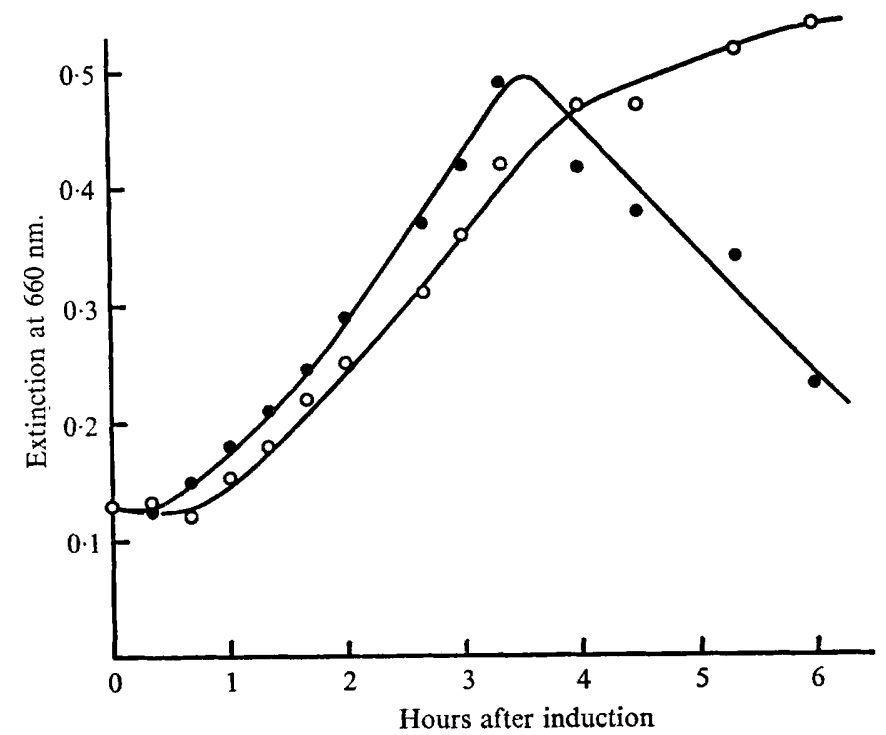

Fig. 2. Effect of mitomycin $\mathrm{C}$ on the growth of $P$. fluorescens strain $3 \mathrm{R}$ at $25^{\circ}$. Control, $\mathrm{O}-\mathrm{O}$; mitomycin-treated,

In spontaneous lysates of older cultures of strain $3 \mathrm{R}$ no rhapidosomal structures were detected (cf. Lewin, I963; Yamamoto, 1967), but they were readily found in mitomycin-induced lysates. Several strains of Pseudomonas aeruginosa or P. fluorescens induced by mitomycin produced rhapidosomes together with R-type but not with 28type pyocin. Correll \& Lewin (I964) analysed purified rhapidosomes obtained from Saprospira and showed that they too were uniform in size with a constant $S$ value and consisted of RNA and protein.

At present all rod-shaped particles released from bacteria are called rhapidosomes, and from these observations it is clear that there are at least two types. However, the rhapidosomal structure whose origin has been proved to be phage-tail or bacteriocin should be called 'polysheath' and not 'rhapidosome'.

The ring structure observed in the lysate at $40^{\circ}$ might be the sheath protein assembled into the ring form or a short rod. Why it is not assembled into complete pyocin has not yet been investigated.

To obtain more direct evidence for the mechanism of polysheath formation we are now trying to isolate sheath protein and reassemble it into polysheaths in vitro.

We thank Mr K. Takemori for the Pseudomonas strains at the Central Laboratory of Kyushu University Hospital, and $\mathrm{Mr}$ A. Takade for his excellent assistance in operating the electron microscope. 
We are greatly indebted to Professor Mary L. Robbins (The George Washington University, Washington, D.C.) for helpful advice in writing this manuscript.

\section{REFERENCES}

BRADLEY, D. E. (1967). Ultrastructure of bacteriophages and bacteriocins. Bacteriological Reviews 3I, 230-314.

Clark-WalKer, G. D. (1969). Association of microcyst formation in Spirillum itersonii with the spontaneous induction of a defective bacteriophage. Journal of Bacteriology 97, 885-892.

CORRELL, D. L. \& LEWIN, R. A. (I964). Rod-shaped ribonucleoprotein particles from Saprospira. Canadian Journal of Microbiology ro, 63-74.

Epstein, R. H., Bolle, A., Steinberg, C. M., Kellenberger, E., Boy de la Tour, E., Chevalley, R., Edgar, R. S., Susman, M., Denhardt, G. H. \& Lielausis, A. (1963). Physiological studies of conditional lethal mutants bacteriophage T4D. Cold Spring Harbor Symposia on Quantitative Biology 28, 375-394.

Hamon, Y. (1956). Contribution a l'étude des pyocines. Annales de l'Institut Pasteur, Paris 9r, 82-90.

Hummeler, K., ANderson, T. F. \& Brown, R. A. (1962). Identification of poliovirus particles of different antigenicity by specific agglutination as seen in the electron microscope. Virology $16,84-90$.

IIDA, H. \& INOUE, K. (1968). Rhapidosomes of Clostridium botulinum type E. Japanese Journal of Microbiology 12, 353-355.

Ishi, S., NisHi, Y. \& Egami, F. (1965). The fine structure of a pyocin. Journal of Molecular Biology 13 428-431.

Kellenberger, E. \& Boy DE LA Tour, E. (I964). On the fine structure of normal and 'polymerized' tail sheath of phage $\mathbf{T} 4$. Journal of Ultrastructure Research $\mathbf{1 1}, 545-563$.

LEWIN, R. A. (1963). Rod-shaped particles in Saprospira. Nature, London 198, 103-104.

Pate, J. L., Johnson, J. L. \& ORdal, E. J. (1967). The fine structure of Chondrococcus columnaris. II. Structure and formation of rhapidosomes. Journal of Cell Biology 35, 15-35.

ReichendaCH, H. (1967). Die wahre Natur der Myxobakterien 'Rhapidosomen'. Archiv für Mikrobiologie $56,371-383$.

TAKAGI, A. \& UEDA, M. (1968). Rod-shaped structure appeared in the autolysed cells of Clostridium botulinum. Japanese Journal of Bacteriology 23, 571-572. (In Japanese.)

TAKeYA, K., Minimishima, Y., Amako, K. \& OHNishi, Y. (I967). A small rod-shaped pyocin. Virology 3I, I66-168.

Yамамото, T. (1967). Presence of rhapidosomes in various species of bacteria and their morphological characteristics. Journal of Bacteriology 94, 1746-1756.

\section{EXPLANATION OF PLATES}

\section{Plate I}

Fig. I. Pyocin induced from the 3R strain of Pseudomonas fluorescens. Two types of pyocin can be seen. One, R-type (R), has a structure like T-even phage-tails; the other, 28-type (28), resembles $\lambda$ phage-tail. R-type pyocin has a contractile sheath. Negatively stained with neutral potassium phosphotungstate (PT). Scale marker represents $100 \mathrm{~nm}$.

Fig. 2. Rhapidosome from strain 3R.

Fig. 3. Rhapidosomes and R-type pyocin from strain 3R. Rhapidosomes ( $\mathrm{RH}$ ) are long rods $\mathrm{I} 80 \AA$ in diameter. Their surface looks granular. Note penetration of PT into the rods.

Plate 2

Fig. 4, 5. Micro-agglutination between rhapidosomes and pyocins. R-type pyocins and 28-type pyocins form different specific agglutinates. Rhapidosomes agglutinate together with R-type pyocins. Antibody bridges can be seen between pyocin rods and rhapidosomes (arrow).

\section{Plate 3}

Fig. 6. Micro-agglutination between rhapidosomes and pyocin. R-type and 28-type pyocin form different agglutinates.

Fig. 7. Lysate from strain $3 \mathrm{R}$ induced at $40^{\circ}$. A large number of small spherical particles can be seen, some of them arranged into short rods (arrows). 

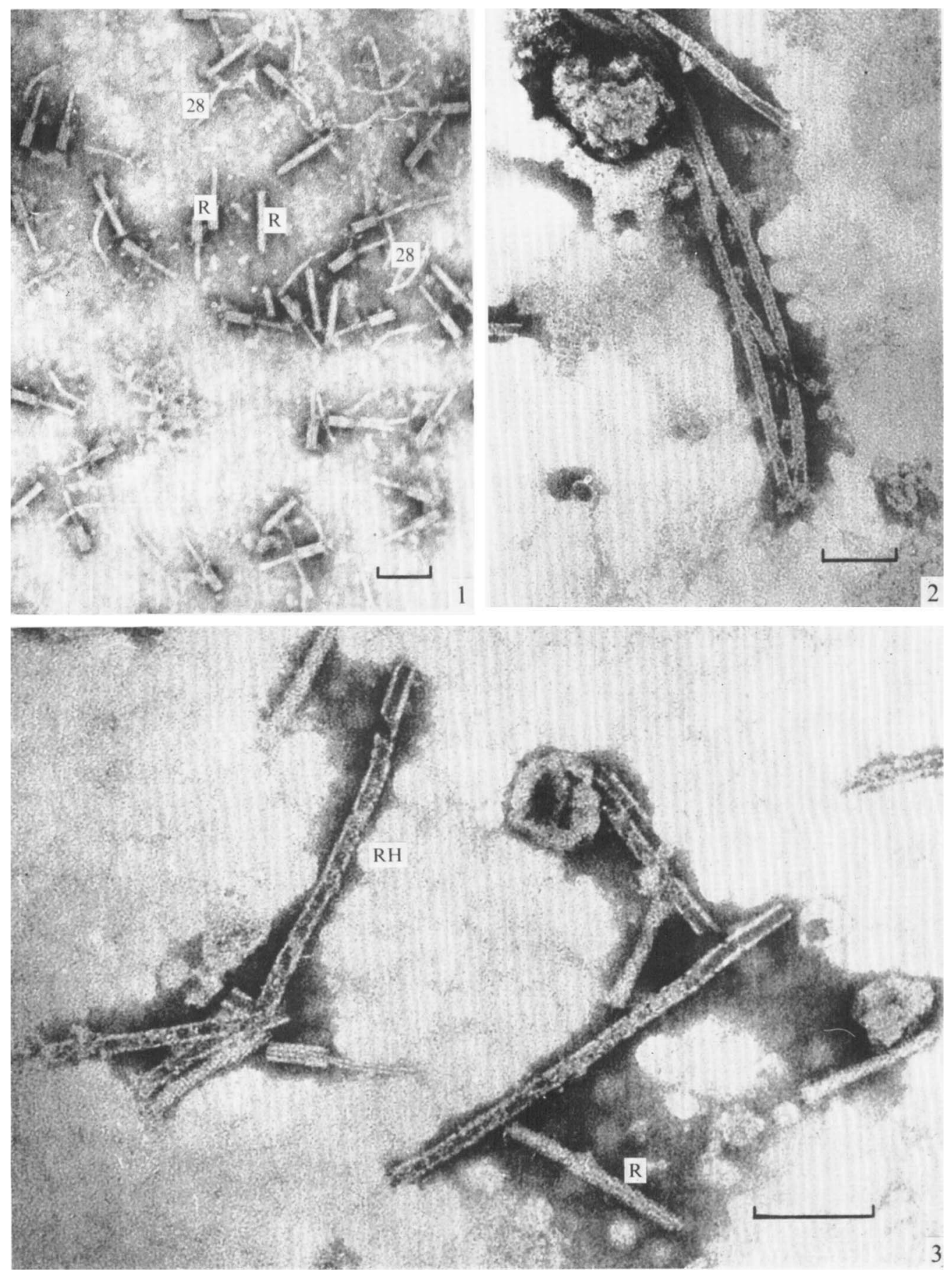

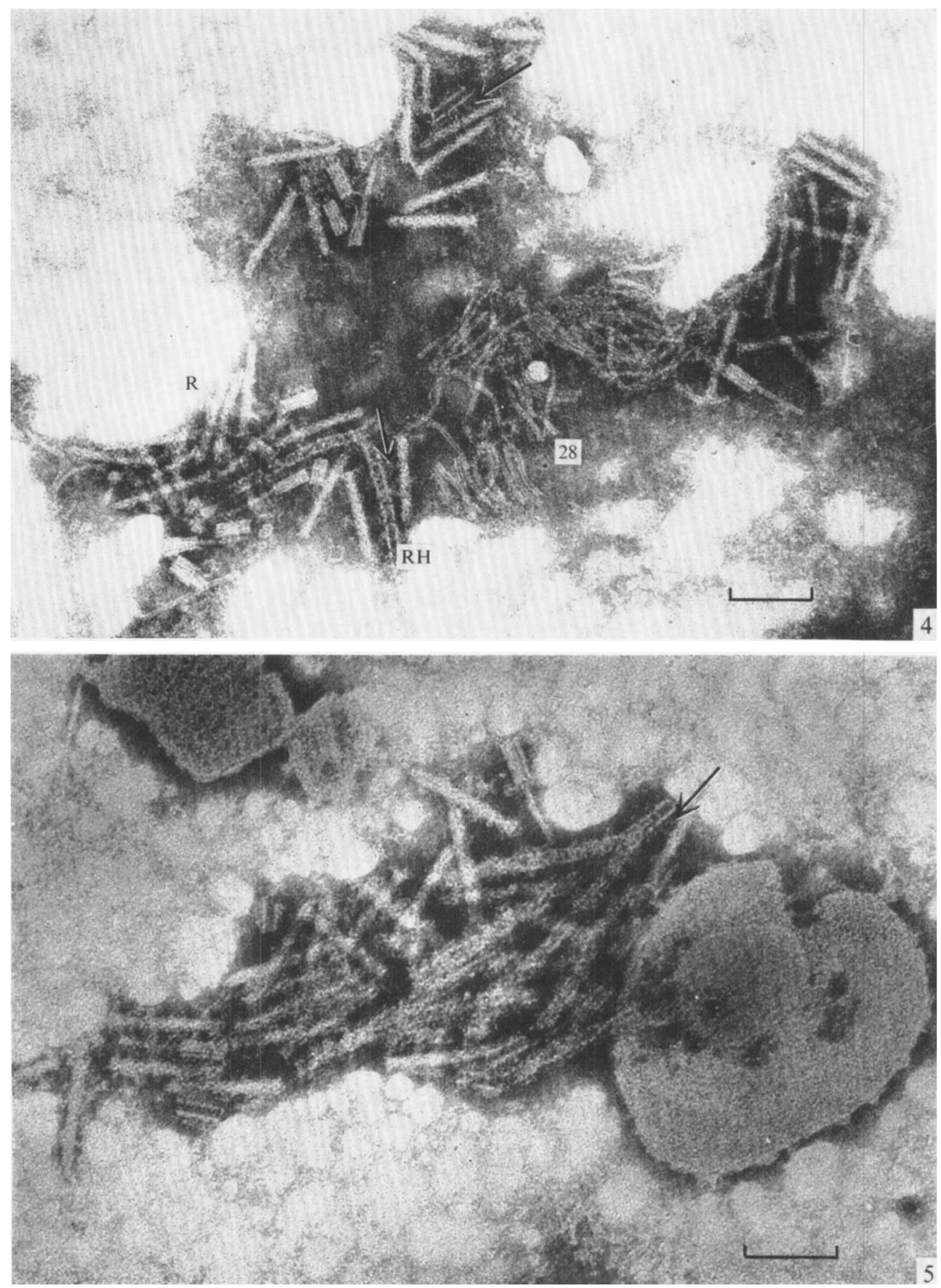

K. AMAKO, K. YASUNAKA ANI K, TAKEYA 

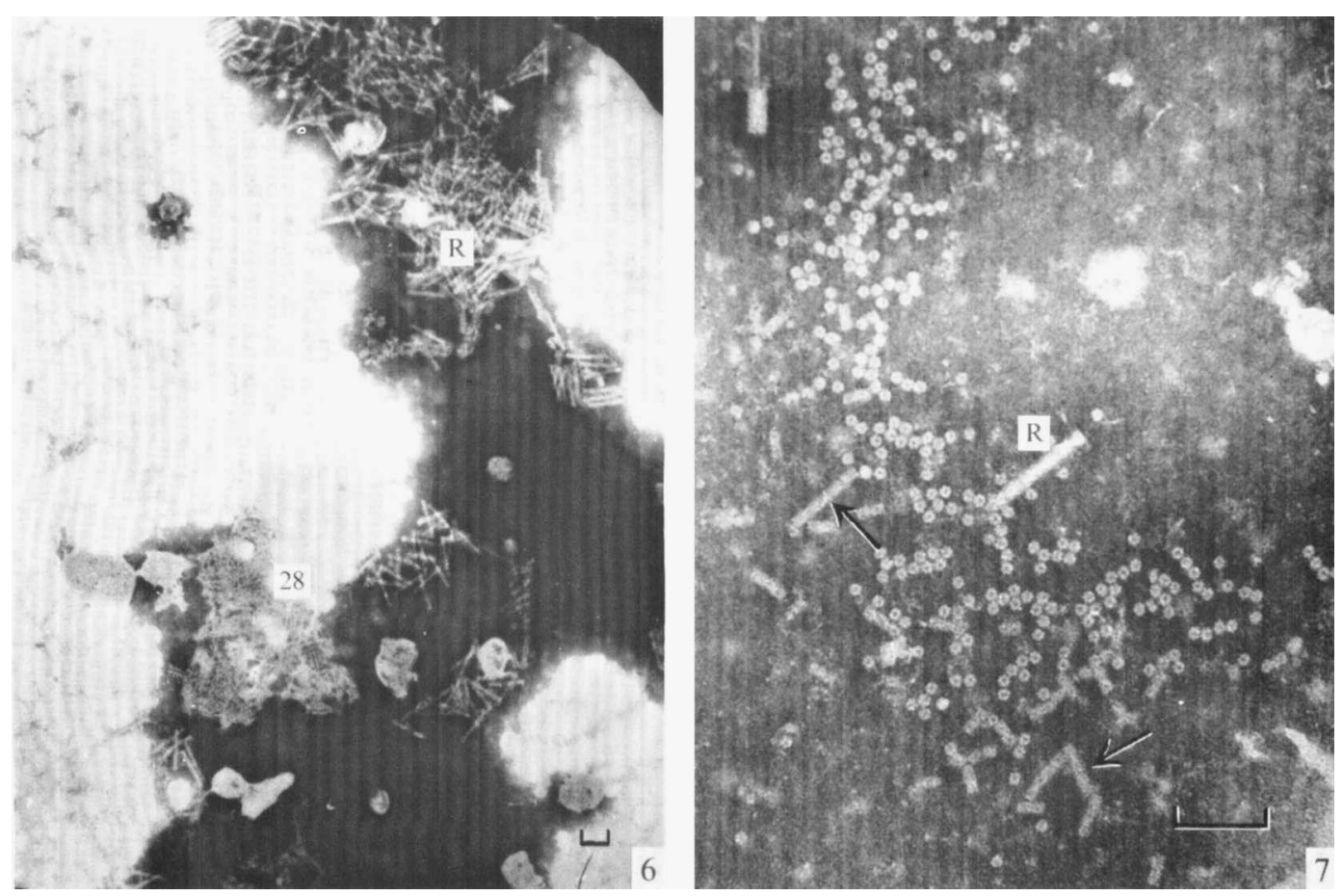